DOI 10.32726/2411-3417-2019-2-76-89

УДК 327; 329

\title{
Вадим ТРУХАЧЁв
}

\section{Словакия в плену противоречий}

Аннотачия. Отношение к РФ в Словакии неоднозначно - страна в этом вопросе расколота, как и близкая ей Чехия. Новым президентом Словакии стала Зузана Чапутова, выступающая с жесткой критикой российской политики. Однако словацкую внешнюю политику определяет правительство, а оно открыто сомневается в целесообразности антироссийских санкций. Значительным влиянием в стране пользуются русофилы, требующие отмены всех ограничений на сотрудничество с Россией и выхода Словакии из ЕС и НАТО. И каждое из имеющихся крупных политических течений олицетворяют три высших должностных лица страны.

Ключевые слова: Словакия, политические партии, Евросоюз, санкции, Россия, Р. Фицо, 3. Чапутова.

$\mathrm{C}$ ловакия имеет давние политические, экономические и культурные связи с Россией. Автором идеи славянской взаимности, к примеру, был словак Ян Коллар, а огромный вклад в развитие связей западных славян с Российской империей внес другой словацкий деятель XIX в. - Павел Йозеф Шафарик. В наши дни Словакия придает большое значение своей принадлежности к славянскому миру: так, день Кирилла и Мефодия 5 июля является здесь не просто памятной датой, как в РФ, а официальным праздником. Даже словацкий флаг напоминает российский.

Но почитание славянских первосвятителей вполне уживается у словаков с тем, что они пишут латиницей и принадлежат в массе своей к Римско-католической церкви. Веками жившие в составе Венгрии и Австрии, словаки в полной мере осознают себя частью Европы, а основой внешней политики их страны уже полтора десятка лет является членство в Евросоюзе и НАТО. Словакия во многом зарекомендовала себя как государство, стремящееся к выстраиванию достаточно тесных связей с Россией и в последние пять лет ставившее под сомнение необходимость антироссийских санкций, но в то же время каждый раз она голосует в ЕС за их продление.

Эта не очень большая страна представляет для России интерес не только в силу своей «славянскости» или же членства в Евросоюзе. Через Словакию (после Украины и далее в Чехию) проходит газопровод, по которому основная часть российского газа идет в Германию и Австрию. И если при прокладке «Северного потока - 2» не принять во

Сведения о6 авторе: ТРУХАЧЁВ Вадим Вадимович - доцент кафедры зарубежного регионоведения и внешней политики Российского государственного гуманитарного университета (РГГУ), кандидат исторических наук; vadimvts@mail.ru. 
внимание те потери, которые Словакия может понести из-за прекращения транзита газа через Украину, то для России не исключены неприятные сюрпризы.

С точки зрения развития российско-словацких отношений и возможности словацких политиков влиять на отношения России и Евросоюза (включая судьбу «Северного потока-2») большое значение имеет расклад различных сил внутри Словакии. Здесь представлены как русофобы (хотя и чуть менее ярые, чем в близкой словакам Чехии), так и открытые русофилы, а также умеренные сторонники развития российско-словацких связей. И все они в той или иной степени имеют возможность воздействовать на внешнюю политику страны.

\section{Антироссийская преемственность президентов}

30 марта 2019 г. в Словакии прошел второй тур выборов президента. Из двух кандидатов более благожелательную к России позицию занимал заместитель председателя Еврокомиссии, еврокомиссар по энергетике, выпускник МГИМО Марош Шефчович. Его поддерживала правящая левоцентристская партия «Курс - социал-демократы». Шефчович, не говоря прямо о необходимости срочно отменить санкции, назвал их «последним инструментом», к которому стоит прибегать. «Россия - это сила, которую нельзя игнорировать, - отмечал он. - Не секрет, что часть словацкого общества очень симпатизирует русской культуре, истории и традиции. Я это уважаю» [Šefčovič straší...].

В то же время М. Шефчович дал понять, что Словакия будет настаивать на сохранении выплат, которые она получает как транзитное государство, через которое российский газ поставляется в Западную Европу. «Для Словакии сейчас важно, что она сохранила деньги за транзит. Это наш национальный интерес. Если речь идет о «Северном потоке-2», то я выступаю за то..., чтобы на данный трубопровод распространялось действие европейских законов» [lbidem]. Очевидно, что считать Шефчовича пророссийским политиком нельзя, хотя резких антироссийских высказываний он себе не позволял.

Однако М. Шефчович выборы проиграл, набрав только 41,6\% голосов, а победительницей стала еще недавно малоизвестный адвокат Зузана Чапутова, которую поддержали 58,4\% избирателей. (Правда, тот факт, что явка составила всего 42\%, делает победу Чапутовой несколько менее значимой.) [Oficiálne...] Ее поддержал решивший не выдвигаться на второй президентский срок Андрей Киска, представители ряда проевропейских и евроатлантических партий либерального и консервативного толка, а также политические силы, представляющие интересы венгерского национального меньшинства.

Новый президент Словакии ранее работала со структурами скандально известного американского миллиардера Джорджа Сороса, и потому не стоит удивляться резкости ее высказываний в отношении России: «Политику Путина считаю угрозой не только Словакии, но и всей Европе... Я вижу стремление подорвать стабильность, демократию и единство Евросоюза... Это серьезная угроза Словакии как части западной цивилизации» [Čaputová...]. 
Похоже, что Чапутова станет продолжательницей политики экс-президента Киски, который в ходе своего президентства отличался резкими заявлениями в адрес России. Так, Киска постоянно выступал с критикой премьеров Фицо и Пеллегрини, которые ставили под сомнение необходимость антироссийских санкций, утверждая, что у противников ограничительных мер «нет видения того, что могло бы прийти им на смену, и как способствовать решению кризиса на Украине» [Kiska...]. «Россия хочет... подорвать ЕС... - уверен бывший президент Словакии. - Наша задача - сохранить ЕС таким, какой он есть» [Rusko se snaží...].

\section{Правоцентристские противники России}

Либерально-консервативная партия НОВА зарекомендовала себя как политическая сила, настаивающая не просто на антироссийских санкциях, но на максимальном замораживании отношений с Россией. «Насильственная аннексия Крыма... и последующая поддержка военного конфликта на востоке Украины возобновили прямую угрозу безопасности Словакии. - говорится в партийной программе. - Российский ревизионизм является главной, хотя и не единственной угрозой для Словакии как члена НАТО и ЕС... Мы будем поддерживать... шаги по снижению энергетической зависимости от России... Мы отказываемся возвращаться к нормальным отношениям с Москвой до тех пор, пока не восстановим те стандарты, которым Россия обязалась следовать и на которых основан европейский и международный порядок» [Program. NOVA].

Входящая в коалицию с партией НОВА консервативная партия «Обычные люди и независимые личности» местами почти слово в слово повторяла заявления о России своих партнеров: «Мы осуждаем нарушение международного права, которое привело к аннексии Крыма и военной интервенции в интересах дестабилизации Восточной Украины. Этот акт, ничем не спровоцированный с Запада, возвращает Россию в самые темные периоды ее истории. Ревизионизм границ как политический принцип угрожает безопасности Словакии, Евросоюза и НАТО. Мы отказываемся возвращаться к нормальным отношениям с Москвой до тех пор, пока не восстановим те стандарты, которым Россия обязалась следовать, и на которых основан европейский... порядок» [OL'ANO...].

Умеренные либералы-евроскептики из партии «Свобода и солидарность» высказывались несколько мягче: «Мы будем благоразумно поддерживать партнерство в более широком контексте отношений Россия - ЕС, с особым учетом энергетического сотрудничества..., которое, однако, может и не носить характер зависимости от России. По этой причине мы также будем поддерживать диверсификацию (источников поставок. - B.T.)» [Strana Sloboda a Solidarita. Volebný program 2016]. Лидер партии Рихард Сулик дал понять, что поддерживает санкции в отношении РФ. «Прибегнуть к экономическим санкциям заставила позиция России, которая не предпринимает реальных шагов по прекращению гражданской войны на востоке Украины» [Strana Sloboda a Solidarita sa vyjadrila...].

Из года в год «Свобода и солидарность» критиковала руководителей Словакии, приезжавших в Россию с визитами. В 2015 г. досталось премьеру Роберту Фицо: «Поездка 
не была необходимой... Фицо долгое время ставил под сомнение необходимость санкций, которые ЕС ввел против РФ за аннексию Крыма и участие в конфликте на востоке Украины... И теперь он просто удостоился внимания российских государственных СМИ» [R. Sulík...]. Спустя три года партия обрушилась с критикой на председателя парламента Андрея Данко: «Данко живет представлениями, что Россия - большая славянская страна, а Словакия - малая, которая на этом основании должна России помогать. Этот подход... опасен, ибо современная внешняя политика строится на интересах безопасности и экономики» [Žiadame].

Председатель распавшейся в 2016-2017 гг. либерально-консервативной парламентской партии «Сеть» Радослав Прохазка также выступал в поддержку антироссийских санкций, объясняя это так: «Для Словакии важно, чтобы... уважение к территориальной целостности соседей было основой международного права. Слова Путина о том, что он будет везде защищать русскоговорящее население, сродни словам Виктора Орбана о том, что он является премьером всех этнических венгров» [Zapojilo sa Rusko...]. Примерно о том же говорится и в программе имеющего депутатов в Европарламенте консервативного Христианско-демократического движения: «Мы отвергаем нарушение международного права и территориальной целостности государств со стороны России» [Volebný program...].

Правоцентристские силы Словакии принадлежат к числу ярых критиков Москвы, не допускающих саму возможность диалога с ней в нынешних политических условиях. Они настроены жестче, чем умеренные евроскептики из «Свободы и солидарности», «Сеть» и христианские демократы. Отчасти такой подход зиждется на страхах перед Россией как правопреемницей Советского Союза, который сохраняется у части словаков (равно как и чехов) после ввода советских войск в Чехословакию в 1968 г. Но еще большую роль играет желание сделать Словакию «ответственным членом Евросоюза и НАTO», которого нельзя даже заподозрить в симпатиях по отношению к России и русским. В некоторой степени словацкими политиками евроатлантического толка движет то, что они опасаются повторения крымского прецедента в населенных венграми южных районах страны. На это, в частности, прозрачно намекал создатель партии «Сеть» Р. Прохазка.

\section{Этнические венгры тоже не за Россию}

На юге Словакии компактно проживают этнические венгры, составляющие почти 10\% населения страны. Они имеют свои партии, своих депутатов Национального совета Словакии и Европарламента. Можно было бы предположить, что их точка зрения во многом близка мнению властей Венгрии... Однако это не касается вопросов отношений с Россией. Если нынешнее венгерское руководство ратует за диалог с РФ и критикует санкционную политику ЕС, то партии венгерского меньшинства в Словакии настроены к Москве куда критичнее.

Консервативное объединение «Партии венгерской коалиции» (ПВК) выступает за сокращение связей с Россией, в том числе в энергетической сфере, и продвижение 
ЕС и НАТО к ее границам. В вопросе расширения НАТО представители этой части словацких венгров ратуют за «открытые двери» и усиление военного присутствия блока в Центральной Европе и Прибалтике, называя Россию «угрозой». ПВК поддерживает европейскую программу Восточное партнерство, но от прямых призывов к скорейшему принятию в ЕС и НАТО Украины воздерживается [SMK-MKP...].

В последние годы большинство словацких венгров голосуют не за ПВК, а за входящую ныне в правительство леволиберальную партию «Мост», которая тоже в целом выступает за жесткую коллективную антироссийскую линию: «Россия из партнера превратилась в стратегического противника... Она нарушает международное право... Возвращение к нормальным отношениям с ней возможно только в случае возвращения международной ситуации в Европе к январю 2014 года... Словакия должна поддерживать каждый шаг, который приведет к объединению мнений ЕС и НАТО против агрессивной внешней политики России» [Most-Híd...]. Определенный нюанс в эту позицию вносит интерес к сохранению определенного уровня экономического сотрудничества. «Мы заинтересованы в хороших экономических связях со странами, расположенными по соседству... - отмечал председатель партии, заместитель председателя словацкого парламента Бела Бугар. - Это не означает, что не надо наказать Россию за аннексию Крыма... Экономически нам следует сотрудничать с Москвой, но в плане политическом говорить не о чем» [Béla Bugár...].

Антироссийский настрой словацких политиков венгерской национальности не подлежит сомнению, и тому есть объяснение. В глазах представителей венгерского меньшинства членство в ЕС и НАТО — известная гарантия их прав, поэтому они стараются действовать в русле политики Брюсселя, а не Будапешта. Во многом их критический подход к России объясняется и памятью об историческом прошлом, когда Российская империя поддерживала боровшееся с венгерской властью словацкое национальное движение. Кроме того, их противники из числа словацких националистов - русофилы, и венгры играют на противопоставлении себя им во всем. Умереннее смотрится партия «Мост», но и ее трудно отнести даже к колеблющимся по отношению к России силам.

\section{Относительная лояльность к России левоцентристов}

Официальную внешнюю политику Словакии на протяжении последних 7 лет определяли преимущественно представители левоцентристской проевропейской партии «Курс - социал-демократия». К ней принадлежат бывший и нынешний премьерминистры Роберт Фицо и Петер Пеллегрини, а также многолетний глава словацкого МИД, выпускник МГИМО Мирослав Лайчак. И во многом благодаря именно усилиям словацких социал-демократов отношения их страны с Россией удалось сохранить на относительно высоком уровне.

Бывший премьер и нынешний руководитель «Курса» Р. Фицо долгие годы имел репутацию лояльно настроенного к России политика. Придя впервые к власти в 2006 г., ОН, не ставя под сомнение членство Словакии в ЕС и НАТО, стал уделять значительное внимание российскому направлению. В 2008 г. Фицо первым из европейских руково- 
дителей заявил, что войну в Южной Осетии развязала Грузия. Когда в 2009 г. случился газовый конфликт между РФ и Украиной, словацкий премьер оказался одним из немногих европейских политиков, возложивших основную ответственность на украинскую сторону [Трухачёв Роберт Фицо...].

В последние же годы Р. Фицо (он ушел в отставку весной 2018 г.) последовательно выступал против антироссийских санкций ЕС и неоднократно бывал в России с визитами. «Нам нужно не гнаться за введением санкций, а поддерживать разумный диалог... - заявил он, находясь в Москве в 2015 г. - Санкции не достигли нужного эффекта, они вредят и Европе, и России» [Fico: Sankcie Rusku ...]. Спустя два года Фицо, оставаясь при своем мнении, дал понять, что Словакия не может идти против воли ЕС и потому вынуждена голосовать за сохранение ограничений: «Если большинство стран считают, что санкции нужно сохранить, я это уважаю» [Robert Fico...]. Кроме того, Фицо выражал обеспокоенность планами России по продвижению проекта «Северный поток-2». Он отмечал, что в случае прекращения транзита газа через Украину его лишится и Словакия, ежегодно получающая за прокачку газа в Германию и Австрию 800 млн евро [Fico po jednání...].

Сменивший Р. Фицо на посту премьера П. Пеллегрини тоже критиковал продление санкционного режима: «Словакия долгое время подчеркивала, что санкции не привели ни к какому позитивному эффекту..., было бы целесообразно рассмотреть вопрос, можем ли мы восстановить конструктивный диалог вместо продолжения бессмысленных санкций, наносящих ущерб экономике нашей страны и российской экономике» [Peter Pellegrini...]. Объясняя, как с такой оценкой ситуации совмещается то, что Словакия в конечном итоге поддерживает санкции ЕС, Пеллегрини использовал следующий довод: «Словакия всегда стоит на стороне своих союзников. Но у нас может быть свое мнение относительно того, чего мы достигли с помощью санкций» [Pellegrini....].

Глава словацкого МИД М. Лайчак всячески подчеркивал важность поддержания диалога с Россией, указывая на необходимость учитывать заинтересованность Словакии «в партнерстве в транзите газа за счет эффективного использования существующей инфраструктуры» [Lajčák: Rusko...]. Подобно своим коллегам по партии, Лайчак при этом не оспаривал не только важность следования Словакии в русле европейской политики, но и сами причины введения санкций: «Словакия не является сторонником санкций. Тем не менее мы являемся членом ЕС и знаем, почему были введены санкции... Я считаю, что настанет день, когда санкции не будут применяться. Однако я не думаю, что ЕС примет одностороннее решение (о снятии санкций. - B.T.) без изменения ситуации» [Lajčák: Únia...].

Отрицательное отношение словацких социал-демократов к политике санкционного давления на Россию мотивируется нежеланием потерять немалые деньги, которые приносит словацкой экономике сотрудничество с РФ. По данным МИД Словакии, в 2013 г. российско-словацкий торговый оборот составлял 8,7 млрд евро. В последующие три года он упал, достигнув в 2016 г. низшего показателя - менее 4, 1 млрд евро. В 2017 г. он вырос до 4,8 млрд., а в 2018-м - уже до 5,6 млрд евро. Но эти цифры очень дале- 
ки от предшествовавших ухудшению отношений между РФ и Западом времен [Ruská federácia... Celkový.... . По состоянию на середину 2018 г. Россия является девятым торговым партнером Словакии (и вторым за пределами ЕС после Китая), но в то же время свыше 75\% нефти и газа словаки покупают именно в РФ [Zahraničný... EU imports...].

Несмотря на столь высокую степень энергетической зависимости от России и ее общую важность как торгового партнера, основой внешней политики Словакии остается членство в Евросоюзе и НАТО, и для социал-демократов оно важнее отношений с Россией. Именно поэтому, несмотря на все сомнения и возражения, они из года в год поддерживали продление санкций. Таким образом, пророссийской силой словацких левоцентристов никак не назовешь - их можно считать лишь относительно лояльными по отношению к России.

\section{Умеренные и радикальные русофилы}

В Словакии существуют и довольно сильные откровенно русофильские партии, одновременно являющиеся евроскептическими. Они во многом опираются на идею славянской взаимности, получившую распространение в XIX в., когда деятели словацкого национального возрождения именно в России видели возможного избавителя от австро-венгерского господства. Но ориентация на РФ имеет и вполне современную идеологическую опору. Россия выглядит как альтернатива Евросоюзу и НАТО, членство в которых принесло Словакии не только выгоды, но и определенные издержки - вроде необходимости воевать в Афганистане или принимать беженцев из стран Ближнего Востока и Африки.

Крупнейшей политической силой такого направления остается евроскептическая Словацкая национальная партия (СНП), входящая в правящую коалицию вместе с «Курсом - социал-демократией» и «Мостом». В ее программе сочетаются отсылки к прошлому и отклики на современные международные проблемы. Не требуя срочного выхода из Евросоюза, партия отмечает необходимость «способствовать развитию торговли между Словакией и... БРИКС и Евразийским союзом». Отдается должное и славянской сущности Словакии: «Мы поддержим развитие идеи славянской взаимности и выработаем общую платформу развития многосторонних связей между славянскими государствами» [SNS...].

Руководитель Словацкой национальной партии, председатель парламента страны Андрей Данко в последние годы неоднократно приезжал в Россию с визитами. Он высказывается за развитие отношений с Россией и скорейшую отмену ограничительных мер: «Санкции ничего не решают, мы должны их отменить... Наши народы близки и по языку, и по культуре. ...Россия является одним из важнейших... торговых партнеров Словакии вне ЕС. Мы вполне можем иметь хорошие связи и на Западе, и на Востоке, и на Севере, и на Юге» [Andrej Danko...].

Представители СНП, вместе с депутатами от Народной партии «Наша Словакия» и партии «Мы семья - Борис Коллар», в 2018 г. посетили Крым. А. Данко поддержал 
эту поездку: «Если словацкие депутаты могли ездить в Косово, независимость которого Братислава не признает, то я не понимаю, почему они вдруг должны воздержаться от посещения Крыма. Я против проявлений русофобии... Ездить в регионы, статус которых является спорным, - одна из задач политиков... Они должны иметь возможность собственными глазами оценить ситуацию в регионе» [Словацкая делегация...].

Более резко высказывались по поводу официальной политики своей страны в рядах националистической Народной партии «Наша Словакия». Лозунги, с которыми партия выступала на выборах 2016 г., звучали весьма красноречиво: «Требуем выхода Словакии из преступного пакта НАТО», «Объявим референдум о выходе Словакии из Евросоюза», «Заменим одностороннюю ориентацию на Запад взаимовыгодным сотрудничеством со всеми странами мира» [L'SNS...]. В том же духе была выдержана программа баллотировавшегося в 2019 г. на пост президента страны лидера этой партии Мариана Котлебы, который занял в итоге четвертое место. Его программу помимо прочего дополнял лозунг «За славянскую взаимность и против войны с Россией» [Slovensko volí...].

Точку зрения партии на российско-словацкие отношения подробно изложил заместитель председателя «Нашей Словакии» Милан Угрик: «Политики и СМИ обвиняют Россию во всех смертных грехах. Запад во главе с США своей агрессивной... политикой стремится поставить Россию на колени... Словакии следовало бы вести взвешенную внешнюю политику и не участвовать в... провокациях, которые организуют в отношении России страны Запада... Санкции против РФ... экономически и политически вредят Словакии, разжигают неприязнь к русскому народу и не несут нашей родине ничего хорошего» [Vyzývame Pellegriniho...].

Помимо откровенных русофилов, в Словакии есть и политики, которых можно считать умеренно пророссийскими, подобно президенту Чехии Милошу Земану. Они не ставят под сомнение евроатлантический выбор страны, однако их в большей степени, нежели правящих социал-демократов, не устраивает политика Евросоюза и НАТО в отношении России. Речь идет об имеющих свою фракцию в парламенте евроскептиках из партии «Мы семья - Борис Коллар». В партийной программе о России прямо не говорится, но ее лидер Борис Коллар выразился достаточно ясно: «Евроатлантическая пропаганда... воспевает деятельность НАТО и Евросоюза и, наоборот, демонизирует Россию... Мы являемся частью западной цивилизации и структур вроде НАТО и ЕС. Но это не означает, что в них все хорошо и их не за что критиковать» [Hnutie Sme Rodina...].

Со своей стороны, занявший третье место на президентских выборах бывший вицепремьер и министр юстиции, ныне беспартийный, Штефан Гарабин, также не оспаривая принадлежность страны к западному сообществу, отдает должное политике России: «Я считаю Россию... стабилизирующим... элементом мировой политики... Без сотрудничества с Россией в Европе невозможны долгосрочный мир и процветание. В таком духе высказываются и некоторые известные немецкие политики. С Путиным сотрудничают даже США под руководством Трампа» [Čaputová: Rusko...]. 


\section{Бывшие руководители в основном не против России}

В Словакии имеется ряд государственных деятелей, которые, покинув высокие должности, продолжают участвовать в политической жизни и высказываться по ключевым моментам внешней политики. Их мнения представляют полный спектр имеющихся в Словакии позиций - от крайне антироссийских до умеренных и даже откровенно русофильских.

Премьер-министр Словакии в 1998-2006 гг. Микулаш Дзуринда в 2014 г. стал внештатным советником президента Украины Петра Порошенко. Для него характерны резкие заявления вроде следующего: «Мы не должны попадать в ситуацию, когда кто-то будет настаивать на отмене санкций против России, в то время как Москва будет продолжать поддерживать «шабаш» в Донецке и Луганске» [Dzurinda...]. В 2018 г. М. Дзуринда призывал Европу вести себя с Россией еще жестче: «Европа должна перейти от традиционной мягкой силы... к жесткой. Мы должны показать нашу силу. И не только для того, чтобы показать, но и для того, чтобы действовать и вмешиваться» [Mikuláš Dzurinda...].

Словацкий президент в 2004-2014 гг. Иван Гашпарович и первый премьер независимой Словакии (1993-1998 гг.) Владимир Мечьяр высказывались о России значительно позитивнее. По словам Гашпаровича, «санкции нанесли ущерб» словацким предпринимателям и ничем не помогли странам Евросоюза; они «нанесли ущерб и России, но кое в чем ей помогли. Страна начала индустриализацию и перестройку сельскохозяйственной отрасли... Санкции помогли России повысить ответственность за свою страну» [Exprezident...].

Со своей стороны, Мечьяр напомнил, что словаки могут задать неприятные вопросы не только России, но и Западу, а потому не стоит усердствовать в антироссийской линии: «Если мы можем подавить наши негативные чувства по отношению к Западу, почему мы пестуем их против России? Зачем нам русофобия?.. Русские добровольно покинули Словакию... Мы расположены между Востоком и Западом. Не забывайте, что наш исторический опыт отличается от других... Мы присоединились к Западу..., но не против Востока» [Danko bol v Rusku...].

Премьер-министра Словакии в 1991-1992 гг. Яна Чарногурского вполне можно отнести к русофильскому лагерю - даже несмотря на его антикоммунистическое, диссидентское прошлое. Он всячески подчеркивает необходимость выстраивания близких отношений с Россией, учитывая тесные исторические связи двух славянских народов: «Никто не может отрицать, что значение России на международной арене постоянно растет... Кроме того, Россия сегодня не коммунистическая страна... А с исторической точки зрения русские в прошлом скорее помогали нам, чем вредили» [Ján Čarnogurský...].

В 2017 г. Я. Чарногурский приезжал в Крым, где высказался за самое тесное стратегическое сотрудничество между Россией и Евросоюзом: «Для Европы... есть альтер- 
натива... Это сотрудничество с Россией. Если бы мы соединили природные богатства, науку и культуру России с технологической развитостью, наукой и культурой ЕС, возникла бы сила мирового значения, знаменующая собой новую победу европейской цивилизации... Нужно будет преодолеть воспоминания о войнах, санкциях и т.п. ... Я верю в такой союз и полагаю, что однажды дело до него дойдет» [Ján Čarnogurský...].

\section{Близость к Чехии при чуть большей русофилии}

Очевидно, что словацкая политическая элита достаточно глубоко расколота по российскому вопросу. Разброс мнений в ней почти столь же широк, как и в близкородственной Чехии [Трухачёв Российский раскол...]. Отличие заключается в том, что в Словакии все же нет партии, которая бы открыто призывала к смене власти в России, как это делает чешская либерально-консервативная «ТОП 09». Подобный по своей резкости подход демонстрирует разве что бывший премьер М. Дзуринда.

Как и в Чехии, в Словакии есть и ярые противники России, и умеренные силы, и открытые русофилы. Степень популярности каждой из точек зрения в какой-то мере можно проследить по результатам выборов, хотя, конечно, голосование отнюдь не всегда определялось отношением кандидатов к РФ. Русофилия в Словакии не преобладает иначе бы главой государства не избрали сначала Андрея Киску, а затем Зузану Чапутову, которым во втором туре противостояли лишь относительно лояльные к России Роберт Фицо и Марош Шефчович. Однако явка на выборах 2019 г. не дотянула и до половины от общего числа избирателей.

Более полную картину симпатий и антипатий дают результаты парламентских выборов 2016 г., когда на участки пришло 60\% словаков, имеющих право голоса. С наиболее антироссийских позиций выступали либерально-консервативная коалиция партий НОВА и «Обычные люди», а также объединение Партии венгерской коалиции, без всяких оговорок называвшие Россию «угрозой». Их суммарный результат составил $16 \%$. Еще $28 \%$ поддержали не столь ярых, но последовательных сторонников сохранения антироссийских санкций из партий «Свобода и солидарность», «Мост», «Сеть» и Христианско-демократического движения. Получается, что санкционные меры Евросоюза против РФ в той или иной степени поддерживает 44\% активных словацких избирателей - не так много, но все же относительное большинство [Parlamentné vol'by 2016...].

Сомневающихся в необходимости санкций, поддержавших партию «Курс - социал-демократия», набралось 28\%. Их можно считать умеренно-благожелательно настроенной к РФ частью словацкого общества. Относительные русофилы из партии «Мы семья - Борис Коллар», к которым заочно примыкали бывший премьер В. Мечьяр и кандидат в президенты Ш. Гарабин, заручились поддержкой 7\% избирателей. Порядка $17 \%$ проголосовали за опирающиеся на идею славянской взаимности Словацкую национальную партию и Народную партию «Наша Словакия». (С ними во многом солидарен бывший премьер Ян Чарногурский). В целом русофилы получили поддержку почти $24 \%$ словаков, что весьма много для государства — члена Евросоюза [lbidem]. 
Если сравнивать словацкое общество с чешским, то словаки в несколько большей степени расположены к России, чем их бывшие соотечественники, хотя расхождение невелико. В Чехии, по итогам выборов 2017 г., наиболее антироссийски настроенные Гражданско-демократическая партия и «ТОП 09» набрали около 17\% при явке в $61 \%$ (напомним - в Словакии аналогичные силы получили 16\%) [Volby do Poslanecké...]. А общая доля так или иначе поддерживающих антироссийскую линию в Словакии (44\%) сопоставима с долей голосов, отданных за проигравшего чешские президентские выборы сторонника санкционного давления на Россию Иржи Драгоша (около 49\% при явке около 67\%) [Volba prezidenta...].

Число словаков, голосовавших за партии, критикующие антироссийские санкции или прямо требующие их отмены, превышает 52\%. Это чуть больше, чем доля голосов за противника санкций Милоша Земана в Чехии (более 51\%). Если сравнить позиции русофилов, однозначно ратующих за снятие санкций, то сумма голосов за чешских коммунистов и националистов из «Свободы и прямой демократии» составила около 19\%. Это несколько меньше числа русофилов в Словакии, но тоже немало. Таким образом, о доминировании антироссийского настроя нельзя говорить даже в чешском случае, а уж в словацком - тем более.

\section{Противоречивая политика «на выходе»}

При таких противоречиях между различными политическими силами Словакии весьма непросто выработать единый курс. Ни одно из мнений по поводу развития российско-словацких связей не является явно преобладающим. Символом неоднозначности словацкой политики может служить пребывание на вершине власти носителей всех трех подходов. Так, президент Чапутова принадлежит к однозначным сторонникам санкций, премьер Пеллегрини - к их проевропейским мягким противникам, а председатель парламента Данко - к требующим их немедленной отмены. В свою очередь, правительство составляют умеренный «Курс - социал-демократия», антироссийский «Мост» и русофилы из Национальной партии.

При таком раскладе сил проводимая премьерами Р. Фицо и П. Пеллегрини политика - «санкции не поддерживаем, но вынужденно голосуем за них в ЕС» - кажется вполне логичной, ибо она является своего рода «средним арифметическим» между крайностями в лице «Новы» и «Нашей Словакии». С высокой степенью вероятности такую противоречивую линию словацкое руководство продолжит и впредь. Тем более что она соответствует истории Словакии как страны, являющейся неотьемлемой частью Европы и католическо-протестантского мира и в то же время связанной многими узами с Россией.

\section{Литература}

Российско-словацкие торгово-экономические отношения // Посольство Российской Федерации в Словацкой Республике. - URL: slovakia.mid.ru/torgovo-ekonomiceskoesotrudnicestvo (date of access: 08.04.2019). 
Словацкая делегация посетит Крым с 1 по 4 августа // Известия.ру. 27 июля 2018. - URL: iz.ru/770626/dmitrii-laru/slovatckaia-delegatciia-posetit-krym-s-1-po-4-avgusta (date of access: 08.04.2019).

Трухачёв В. Роберт Фицо: друг России из центра Европы // Правда.Ру. 07.10.2012. pravda.ru/ world/1130444-Fico/ (дата обращения: 08.04.2019).

Трухачёв В. «Российский» раскол Чехии // Перспективы. Электронный журнал. 2018. №3. С. 100-113. — URL: perspektivy.info/upload/iblock/863/3_2018_7_00_Trukhachev_100_113.pdf (дата обращения: 08.04.2019).

Andrej Danko: Som rád, že sa potvrdzujú moje slová, že svet musí spolupracovat' s Ruskom // Slovenská národná strana. 7. októbra 2018. — URL: sns.sk/andrej-danko-som-rad-ze-sapotvrdzuju-moje-slova-ze-svet-musi-spolupracovat-s-ruskom/ (date of access: 08.04.2019).

Béla Bugár: Budem znovu kandidovat’ vo vol'bách, ak ma dovtedy neporazí// Most-Híd. 23.11.2017. — URL: $\quad$ most-hid.sk/sk/bela-bugar-budem-znovu-kandidovat-vo-volbach-ak-ma-dovtedyneporazi (date of access: 08.04.2019).

Čaputová: Rusko je pre nás hrozbou...// Hlavné Správy.sk. 13 marca 2019. — URL: hlavnespravy. sk/caputova-rusko-je-pre-nas-hrozbou-harabin-rusko-predstavuje-pod-vedenim-putinastabilizacny-prvok-vo-svetovej-politike-bezpecnosti/1696878 (date of access: 08.04.2019).

Celkový dovoz a celkový vývoz podla kontinentov a ekonomických zoskupení krajín// Štatistický úrad Slovenskej Republiky, 07.06.2019. — URL: https://clck.ru/HSif3 (date of access: 13.06.2019).

Danko bol v Rusku, no a čo? // Vladimír Mečiár — osobná stránka. 23. novembra 2017. — URL: vladimirmeciar.sk/danko-bol-v-rusku-no-co/ (date of access: 08.04.2019).

Dzurinda: Tak trochu by sme sa mali všetci spamätat' // Aktuality.Sk. 18.12.2015. — URL: aktuality. sk/clanok/310303/dzurinda-tak-trochu-by-sme-sa-mali-vsetci-spamatat/ (date of access: 08.04.2019).

EU imports of energy products - recent developments // Eurostat. October 2018. — URL: ec.europa. eu/eurostat/statistics-explained/pdfscache/46126.pdf (date of access: 13.06.2019).

Exprezident Gašparovič je presvedčený, že sankcie proti Rusku budú zrušené// Napalete.Sk. 19. mar 2017. - URL: napalete.sk/exprezident-gasparovic-je-presvedceny-ze-sankcie-protirusku-budu-zrusene/ (date of access: 08.04.2019).

Fico po jednání s Putinem: Rusko je v energetice spolehlivý partner // Eurozprávy.Cz. 26. srpna 2016. — URL: eurozpravy.cz/zahranicni/evropa/166752-fico-po-jednani-s-putinem-rusko-jev-energetice-spolehlivy-partner/ (date of access: 08.04.2019).

Fico: Sankcie Rusku škodia, zrušme ich // Pravda.Sk. 02.06.2015. - URL: spravy.pravda.sk/ domace/clanok/357071-fico-v-rusku-nepotrebujeme-rincanie-zbranami-ani-sankcie/ (date of access: 08.04.2019).

Hnutie Sme Rodina vyhlásilo vojnu mimovládnym organizáciám // Medzičas.Sk. 29.07.2016. — URL: medzicas.sk/hnutie-sme-rodina-vyhlasilo-vojnu-mimovladnym-organizaciam/ (date of access: 08.04.2019).

Ján Čarnogurský: Krym a Európa // Slovensko-ruská spoločnost'. Jalta, 06.11.2017. — URL: srspol. sk/clanek-jan-carnogursky-krym-a-europa-15424.html (date of access: 08.04.2019).

Ján Čarnogurský: Veril som, že z bývalého disidenta by mohol byt' dobrý prezident // BratislavskéNoviny.Sk. 24.11.2018. — URL: bratislavskenoviny.sk/rozhovory/52167-rozhovorjan-carnogursky-veril-som-ze-z-byvaleho-disidenta-by-mohol-byt-dobry-prezident (date of access: 08.04.2019).

Kiska: Spochybňovat' protiruské sankcie je nezodpovedné // Pravda.sk. 16.03.2017. — URL: spravy. 
pravda.sk/domace/clanok/423285-kiska-spochybnovat-protiruske-sankcie-je-nezodpovedne/ (date of access: 08.04.2019).

Lajčák: Rusko vnímame ako dôležitého hospodárskeho a obchodného partnera// Noviny.Sk. 06.06.2017._URL:noviny.sk/229394-lajcak-rusko-vnimame-ako-doleziteho-hospodarskehoa-obchodneho-partnera (date of access: 08.04.2019).

Lajčák: Únia len tak nezruší sankcie proti Rusku // Pravda.Sk. 10.10.2018. — URL: spravy.pravda. sk/svet/clanok/487463-lajcak-unia-len-tak-nezrusi-sankcie-proti-rusku/ (date of access: 08.04.2019).

L'SNS. Volebný program 2016. — URL: naseslovensko.net/wp-content/uploads/2015/01/Volebnýprogram-2016.pdf (date of access: 08.04.2019).

Mikuláš Dzurinda vyzval NATO a EÚ na použitie hard power voči Rusku // HlavnéSprávy.Sk. 23. marca 2018. - URL: hlavnespravy.sk/mikulas-dzurinda-vyzval-nato-eu-na-pouzitie-hard-powervoci-rusku-putinova-reakcia-je-samousvedcenie/1350020\# (date of access: 08.04.2019).

Most-Híd. Občianska vízia. — URL: obcianskavizia.sk/ (date of access: 08.04.2019).

Oficiálne výsledky druhého kola prezidentských volieb 2019 // Sme.sk. 01.04.2019. — URL: domov. sme.sk/c/22087839/kompletne-vysledky-prezidentskych-volieb-2019-2-kolo-minuta-pominute.html (date of access: 13.06.2019).

OL'ANO. Náš program pre Slovensko. — URL: obycajniludia.sk/program/zahranicna-politika/ (date of access: 08.04.2019).

Parlamentné vol'by 2016 - výsledky // Volby.Sme.sk. - URL: volby.sme.sk/parlamentnevolby/2016/vysledky (date of access: 13.06.2017).

Pellegrini: Sankciami proti Rusku sme nedosiahli dokopy nič // Sme.Sk. 10 okt 2018. — URL: domov.sme.sk/c/20934562/pellegrini-rusko-sankcie-danko-lajcak-unia-moskva. html\#ixzz5gHdP5AgG (date of access: 08.04.2019).

Peter Pellegrini: Sankce vưči Rusku jsou nesmysl // VlasteneckeNoviny.Cz. 28.06.2018. — URL: vlasteneckenoviny.cz/?p=201901 (date of access: 08.04.2019).

Program. NOVA. — URL: nova.sk/app/webroot/media/content/files/PROGRAM_NOVA_3.pdf (date of access: 08.04.2019).

R. Sulík: Výsledkom premiérovej cesty do Ruska je len pocit trápnosti// Strana Sloboda a Solidarita. 3. jún 2015. URL: sas.sk/detail/1329/r-sulik-vysledkom-premierovej-cesty-do-ruska-je-lenpocit-trapnosti/obsah (date of access: 08.04.2019).

Robert Fico by d'alšie sankcie voči Rusku už nikdy nepodporil // Aktuality.Sk. 04.02.2017. — URL: aktuality.sk/clanok/412668/robert-fico-by-dalsie-sankcie-voci-rusku-uz-nikdy-nepodporil/ (date of access: 08.04.2019).

Ruská federácia. Ekonomická informácia o teritóriu. 2018 // Ministersvo zahraničných vecí a evropskych záležitostí Slovenskej Republiky. — URL: mzv.sk/documents/747511/620840/ Rusko+-+ekonomické+informácie+o+teritóriu+2018 (date of access: 13.06.2019).

Rusko se snaží rozštěpit EU, varoval slovenský prezident Kiska před kremelskou propagandou // ČT24. 23.04.2018. — URL: ct24.ceskatelevize.cz/svet/2459224-rusko-se-snazi-rozstepit-euvaroval-slovensky-prezident-kiska-pred-kremelskou (date of access: 08.04.2019).

Šefčovič straší: Alternativou silné EU je Slovensko závislé na jiných mocnostech // Sputnik Česká republika. 20.02.2019. — URL: cz.sputniknews.com/slovensko/201902209262486-sefcovicstrasi-alternativou-eu-slovensko-zavisle-mocnosti/ (date of access: 08.04.2019).

Slovensko volí. Podpůrce tradiční rodiny a slovanské vzájemnosti Kotleba // Sputnik Česká republika. 20.02.2019. - URL: cz.sputniknews.com/slovensko/201902209263617-slovensko- 
prezidentske-volby-2019-kandidat-marian-kotleba/ (date of access: 08.04.2019).

SMK-MKP. Volebný program strany mad'arskej komunity. — URL: drive.google.com/file/d/OBuFWu08PUjObUI2NDFjSHI4cUk/view (date of access: 08.04.2019).

SNS. Volebný program pre silný štát 2016-2020. — URL: sns.sk/wp-content/uploads/2017/04/ volebny_program_2016.pdf (date of access: 08.04.2019).

Strana Sloboda a Solidarita sa vyjadrila v prospech sankcií // Medzičas. 15.08.2014. — URL: medzicas.sk/stana-sloboda-a-solidarita-sa-vyjadrila-v-prospech-sankcii/ (date of access: 08.04.2019).

Strana Sloboda a Solidarita. Volebný program 2016. — URL: sas.sk/detail/4065/nr-sr-2016/subory (date of access: 08.04.2019).

Volba prezidenta republiky konaná ve dnech 12.01. - 13.01.2018 // Volby.cz - Výsledky voleb a referend. — URL: volby.cz/pls/prez2018/pe2?xjazyk=CZ (date of access: 13.06.2017).

Volby do Poslanecké sněmovny Parlamentu České republiky konané ve dnech 20.10 - 21.10.2017 // Volby.cz — Výsledky voleb a referend. — URL: volby.cz/pls/ps2017/ps2?xjazyk=CZ (date of access: 13.06.2017).

Volebný program KDH 2016. — URL: kdh.sk/wp-content/uploads/2016/01/volebny_program_web. pdf (date of access: 08.04.2019).

Vyzývame Pellegriniho, aby zastavil protiruské besnenie a nehlasoval za predľženie sankcií // L'udová strana Naše Slovensko. 11. decembra 2018. — URL: naseslovensko.net/nase-nazory/ zahranicna-politika/vyzyvame-pellegriniho-aby-zastavil-protiruske-besnenie-a-nehlasovalza-predlzenie-sankcii/ (date of access: 08.04.2019).

Zahraničný obchod SR — január až august 2018 // Ministerstvo hospodárstva SR. — URL: economy. gov.sk/uploads/files/BqaMkZrL.pdf (date of access: 13.06.2019).

Zapojilo sa Rusko aktívne do konfliktu na Ukrajine? // Denník N. 24. februára 2015. — URL: dennikn.sk/56563/zapojilo-sa-rusko-aktivne-konfliktu-na-ukrajine-anketa/ (date of access: 08.04.2019).

Žiadame P. Pellegriniho a M. Lajčáka, aby odsúdili servilnú proruskú politiku A. Danka // Strana Sloboda a Solidarita. 5. jún 2018. — URL: sas.sk/detail/4272/ziadame-p-pellegriniho-a-mlajcaka-aby-odsudili-servilnu-prorusku-politiku-a-danka/obsah (date of access: 08.04.2019). 